\title{
The Effect of Culture - Based Approach in Improving Students' Reading Comprehension on Spoof Text
}

\author{
Rudi Suherman, rudipipit11@gmail.com, English Education Program, \\ Universitas Persatuan Islam, Bandung, Indonesia

\begin{abstract}
Ana Yusyfiana, yusyfiana@gmail.com, English Education Program, Universitas Persatuan Islam, Bandung, Indonesia
\end{abstract}

\begin{abstract}
This research was intended to investigate the effect of culture-based approach in improving students' reading comprehension on spoof text. For that purpose, a true experimental study was employed to the eleventh-grade students of SMAN 1 Soreang. The sample of this study was 88 students. These students were divided equally into a control and experimental group. During the research, the experimental group were given the Culture - Based Approach (CBA) as the treatment. The students' scores of pre-test and post-test from both groups were statistically analyzed and compared by T-test. The classroom observation was also implemented to depict problem faced by the students when the approach was given. The findings could be summarized that generally students from the experimental group gained better score compare to the control group on their posttest score. The data analysis also showed that there was a significant difference between the mean score of the pre - test (53.45) and the post-test (58.39.). Furthermore, the result of the t-test (5.707) was relatively higher than the t- table (2.018) for 0.5 percent level of significance. It indicated that the students' achievement was significantly improved after the treatment. Although the observation result showed that the students' lack of vocabularies hinders them to comprehend the twist in the spoof text, they were still able to follow the teaching learning process and coped with the problem they faced. Therefore, CBA can be considered as an alternative choice for EFL teachers when teaching spoof text as it enables to improve students' reading comprehension.
\end{abstract}

Keywords: Culture-Based Approach (CBA), Genre-Based Approach (GBA), students' reading comprehension, Spoof text.

\section{A. INTRODUCTION}

For more than six decades, research and practices in English language teaching have identified the "four basic skills" -listening, Speaking, Reading, and Writing. The latter is highly determined as the culmination of the other skills. Writing skill which is categorized as productive skill defined as a nonverbal communication that is used to express feeling and thought (Phillips and Stern, 1986). In addition, it has essential roles in all aspect of life. It is also stated that a big nation is a nation whose citizens love writing. Therefore, writing skill should be taken as a part of cultural literacy that can be used as a media for self-development in which language and culture are interrelated,

162 | IJET| Volume. 9, Issue 2. December 2020

Copyright 2020 Rudi Suherman, and Ana Yusyfiana are licensed under Creative Commons Atrribution-

ShareAlike 4.0 International License 
language cannot be taught without teaching culture either explicitly or implicitly (Alwasilah and Haedar, 2011).

There are many ways of co-teaching language and culture, one of them is through teaching and learning texts (Lim, 2018). Texts are produced by socially situated speakers and writers. It means that the relation between the speaker and the writers in producing texts are not always the same. It is also highlighted that language affects how a culture conceptualizes reality. Different languages evolved different ways of seeing. Yet, when (Chomsky, 1965) focused linguistic inquiry upon a universalist quest for the structures that underlie all language. Therefore, the position of culture and language became unfashionable. The culturally shaped differences among languages appeared trivial when compared to their common, underlying features.

In the context of Indonesia, writing becomes an essential skill that needs to be master by the students. As a result, since 2004, followed by curriculum 2013, Indonesian Ministry of Education and Culture (Kemendikbud) has adopted the aim of English curriculum which involves an approach that attempts and emphasizes on writing skill known as Genre-Based Approach (henceforth GBA) (Ningsih, 2016; Emilia and Hamied, 2015). Consequently, there are several texts that are compulsory taught at the level of junior and senior high school. The types of text or genre that are placed in curriculum such as narrative, descriptive, recount, spoof and many others.

This curriculum aims to facilitate the students to be able to write functionally based on the genre being learned. Therefore, the students are guided to comprehend the text, not only the social function, generic structures of the text, but also to comprehend the content of the text itself. Briefly, it is expected that Indonesian students eventually can compose the same text by their own writing skill as the main goal of this approach functionally and meaningfully Evha \& Sa'adiyah, (2019) as well as a to develop interest in reading and writing to actively participate in the globalized world (Ningsih, 2016).

However, the students often face difficulties to comprehend the content of the text that the teachers teach in the class. It is likely because of the students' reading comprehension level which still low (Perwira, 2019). It is generally known that before the students are able to write a type of text which is in accordance with the its social function, grammatical features and generic structures, they need to gain the information as the source of ideas that can be transform into a piece of writing. It can only be accomplished if the students 'exposure to reading a lot and have decent reading comprehension. According to this fact, the first step that they essentially require prior to have high level of writing skill is having decent level of reading comprehension (Renandya, 2007). In summary, it becomes the first gate for the students before reproducing the text that they wish to make. As Emilia, (2012) states as follow;

Writing and reading are social activities which are interrelated to each other. People always read something, written by someone or writing something for someone. It is always in some relationship to us -often materially or symbolically unequal relationships of power but always relationships in which versions of 'ourselves 'and 'others 'are implicated and constructed. Even those texts that people read or write that

163 | IJET| Volume. 9, Issue 2. December 2020 
come from or are intended for people who do not know assemble versions of one's identities and positions as readers -as men and women, students and teachers, taxpayers, and newspaper readers and so forth .... (Emilia, 2012)

Therefore, writing skill cannot be separated from reading as one of systems that interdependent each other. On other words, reading comprehension should be put forward before writing does (Booth, 2007). Reading as a receptive skill, becomes a key issue and a milestone for a better writing skill (Elgort et al. 2018; Setiawan and Ena 2019). One will certainly be unable to write well, if he/she doesn't read well.

A type of text that is taught and relatively difficult to comprehend is the text that needs culture comprehension such as spoof text. It is a kind of text that retells an event with a humorous twist (Handayani \& Harha, 2016). This text originally composed as an interesting text that closed - real life situation in order to make the reader easy to follow it. Even more, the humor twists as one of generic structure part of this text purposes to trigger the readers to laugh after reading it.

Spoof text is usually taught in the first semester of 11 grade. Its generic structures are orientation; set the scene by telling who are involved, where is the circumstance and the plot, event(s);-tell what happened, and sometimes it is also accompanied by a problem or an issue facing by the characters. It resolves by a twist which provides the punch line or unpredictable humor. In certain condition, it is hardly to identify and differ between spoof and recount or anecdote since reading spoof and recount text will initiate the convenience both spoof and recount text explore the informative fact for the past experience. In literary term, experience can be factual, imaginative, objective or subjective. Both text focus on series of event that happened in the past.

However, for functional view, recount text emphasizes in detailed information of the event. It reveals the series of the events in chronological order based on the time and place. On the other hand, spoof text tends to project the amusement of reading (Handayani \& Harha, 2016). Spoof text uses tricky plot to drive the reader to certain view and eventually bring the reader to the opposite point, this trick is commonly known as punch line.

Clearly the distinguish flow plot used by both text are seen at the applied generic, for the first stage, both of the introduce the participants, time and place of the story, then the texts expose the following events in detailed, in the last phase is what make them different, recount text will summarize the introduction and close with the writer's personal opinion regards to the story, meanwhile spoof text will end the story with what it is called as a twist, it is unpredictable ending that readers are unable to anticipate.

The problem arises since the students have different cultures which affects their sense of humor and this situation becomes a big barrier for the students tocomprehend spoof text thoroughly. As it is recognized that every text is woven based on two contexts; they are context of situation and context of culture. Spoof text highly

164 | IJET| Volume. 9, Issue 2. December 2020 
emphasizes the context of culture. It refers to a broader background against which the text has to be interpreted (Emilia, 2012; Emilia \& Tehseem, 2013; Emilia \& Hamied, 2015). Therefore, Culture Based - Approach (henceforth CBA) is urgently required to bridge and solve this matter, particularly the culture context of how the native speakers construct humor in particular humor lies in spoof text.

Considering the CBA as a way to improve students' reading comprehension on spoof text, the researcher attempts to reveal the effect of this approach by using certain specific situations where students can compare, differ and identify how the native speaker builds humor on spoof text. It is expected that the students will eventually be able to realize that spoof does indeed contain humorous parts that make them understand all the essential elements of the text and have a joyful reading.

\section{B. METHOD}

This research aims to (1) investigate the effect of using culture-based approach in improving student's comprehension on spoof text and (2) to reveal problem that the students face when the spoof text is being taught.

In order to achieve the first research objective, the true experimental design is employed in this research. Since the essential ingredient of a true experimental design is that subject are randomly assigned to treatment group. Therefore, it is a powerful technique for controlling the subject characteristic threat to internal validity, a major consideration in educational research Jack, Norman, \& Wallen, (2017) and considering that it is the applicable approach as the nature of the research. In order to collect the data, the pre-test and post-test are employed to 88 students from experimental and control groups who participate in this study. Schematically, the research design is represented as follow:

Table 1. Research Design

\begin{tabular}{l|lcr} 
EG & TIE & X & T2E \\
\hline CG & TIC & & T2C
\end{tabular}

Note:

$\mathrm{EG}=$ Experimental Group

$\mathrm{CG}=$ Control Group

TIE $=$ Pre-test of Experimental Group

TIC $=$ Pre - test of Control Group

$\mathrm{T}=$ Treatment

165 | IJET| Volume. 9, Issue 2. December 2020 Copyright 2020 Rudi Suherman, and Ana Yusyfiana are licensed under Creative Commons AtrributionShareAlike 4.0 International License 


\section{$\mathrm{T} 2 \mathrm{E}=$ Post-test of Experimental Group \\ $\mathrm{T} 2 \mathrm{C}=$ Post - test of Control Group}

The procedures that are conducted in this research consist of seven (7) steps, they are; firstly (1) administering the pre-test to both groups, the experimental and the control group, then (2) implementing CBA to the experimental group as a treatment, if the treatment has implemented to the experimental group, then to find out the significance of this research, hence,(3) administering the post-test to both groups as the next step, (4) collecting the resulted data. Fifthly, (5) the data will be analyzed through certain statistical formula, to figure out the reliability and validity of both data, pre-test and post-test. Sixthly, (6) the data will be interpreted to make the data easier to be understood. (7) Finally, the observation results are interpreted.

The pre-test is administered to capture the initial score of each student. There are 44 students from each group who participate in the pre-test. They are asked to read a spoof text that has been prepared by the teacher. They read it silently for 25 minutes. After that, they are requested to answer the questions based on the text given. The questions are in multiple choice and long answer questions. These questions are given to capture their initial reading comprehension in regard with the text, particularly the humorous or twist part as a distinctive feature of spoof with the other texts.

The treatment is given after the pre-test. The experimental group is taught about spoof text using CBA. It is started by teaching them the basic element of CBA on building knowledge of the field phase, then it is gradually continued by finding students' feedback toward the approach. The treatment is conducted four-time consecutively during four-week of the study.

The post-test is intended to get the score after receiving the treatment, and to compare the score between the pre-test and the post-test. Procedure of the post-test is quite similar to the pre-test. The students are requested to read another spoof text that has been prepared. In addition to this, they are requested to answer the questions based on the given text. The questions, related to the text, are in multiple choice and longanswer questions.

The data analysis is employed to determine if there is significant effect between the mean score of pretest and posttest of both groups. The score of 88 students who take the test are calculated using a certain statistical formula on Statistical Package for the Service Solution (SPSS) software. This software is used in order to minimalize miscalculation if calculate manually and for time -efficiency.To answer the second research objective, the classroom observation is implemented during four-week of the study. The researcher files note on the behavior and activities of the students particularly on the problem that they probably face when learning spoof text. The researcher also records, in an activity at the research site and collect their works followed by an unstructured or semi structured way using some prior questions that the inquirer wants to know (J. W. Creswell, 2007; J. Creswell, 2013). The interview

166 | IJET| Volume. 9, Issue 2. December 2020 
questions are prepared as the guideline in order to make it in accordance with the research objective proposed and to clarify the subtle findings during the observation.

\section{RESULT AND DISCUSSION}

The data of this research gained from the pre-test and post -test of both groups; experimental and control groups and classroom observation during the four-week of study. The tests were in the form of multiple and long answer questions. Those test results were scored, calculated and compared using statistical computational software. Below the comparison of mean between both groups; experimental and control group.

Table 2. Mean Score of Pre-test

\section{Group Statistics}

\begin{tabular}{|l|l|l|l|l|}
\hline Group & $\mathrm{N}$ & Mean & $\begin{array}{l}\text { Std. } \\
\text { Deviation }\end{array}$ & $\begin{array}{l}\text { Std. Error } \\
\text { Mean }\end{array}$ \\
\hline $\begin{array}{l}\text { Score } \\
\begin{array}{l}\text { experimental } \\
\text { group }\end{array}\end{array}$ & 44 & 53.45 & 13.982 & 2.108 \\
control group & 44 & 54.09 & 18.681 & 2.785 \\
\hline
\end{tabular}

The statistical computation results have showed that CBA has positive effect in improving students 'reading comprehension on spoof text. It is proven by comparing the mean score of experimental and control groups. The calculation of pre-test scores shows the mean of the experimental group is 53.45 and control group is 54.09. The result of pre-test using independent sample T-test available in SPSS shows that there is no significant difference between the mean of experimental group and control group ( $\mathrm{p}$ $>0.05$, in which $p=0.290$ ). It means that both groups have the equal comprehension in spoof text before the treatment addressed to the Experimental Group.

Table 3. Mean Score of Post-test

Group Statistics

\begin{tabular}{|l|l|l|l|l|}
\hline Group & $\mathrm{N}$ & Mean & $\begin{array}{l}\text { Std. } \\
\text { Deviation }\end{array}$ & $\begin{array}{l}\text { Std. Error } \\
\text { Mean }\end{array}$ \\
\hline $\begin{array}{l}\text { Posttest } \\
\text { Experimental } \\
\text { group }\end{array}$ & 44 & 58.39 & 14.527 & 2.190 \\
\hline
\end{tabular}

167 | IJET| Volume. 9, Issue 2. December 2020 Copyright 2020 Rudi Suherman, and Ana Yusyfiana are licensed under Creative Commons AtrributionShareAlike 4.0 International License 


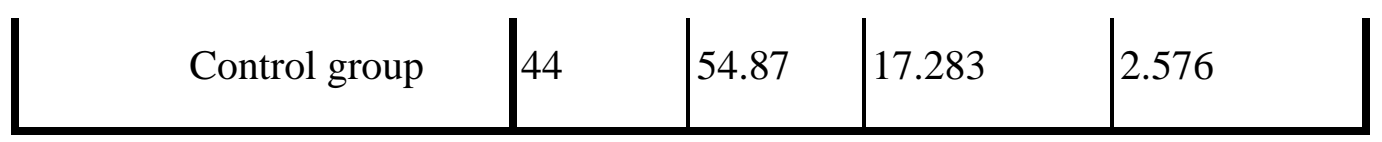

After the treatment by implementing the CBA, the calculation of post-test scores shows the mean of experimental group 58.38 and control group is 54.86 using SPSS. The results of the posttest using an independent sample t-test available in SPSS shows that there is a significant difference between the mean of experimental group and control group ( $\mathrm{p}<0.05$, which $\mathrm{p}=0.000$ ). It can be concluded that the mean of the experimental group is statistically higher than the control group, and the mean difference is statistically significant. Thus, the null hypothesis is rejected. It means that the experimental group has better comprehension in spoof text than the control group.

In addition, the score gained by the experimental group in the post-test compared to the pre-test shows that the enhancement is statistically significant. The mean gained in pre-test is 53.45 and posttest is 58.38. the result of the t-test (5.707) was relatively higher than the $\mathrm{t}$ - table (2.018) for 0.5 percent level of significance. It indicated that the students' achievement was significantly improved after the treatment of using CBA. It can be inferred that the mean of post-test is statistically higher than pre-test, and the mean difference is statistically significant. Thus, the alternative hypothesis is accepted.

The CBA is statistically proven and can help students to improve their reading comprehension on spoof text. It is in line with the statement of (Engelbart, 2004) that describes: "...to teach a foreign language is also to teach a foreign culture". In terms of teaching English text or genre, it is advisable to incorporate culture as the approach of the teaching.

This result is also generally supported by classroom observation that had been conducted. It was found that the students in the sample of the research were able to follow the series of how native speakers construct the humor in terms of spoof text as the most important part in CBA in improving student's reading comprehension. When the researcher gave comparative and group discussion study between Indonesian and American humor. The students are actively engaged in the discussion session. They discuss its history, characteristics, the similarity and the differences of humor between Indonesia and other countries (Vivona, 2014). Further, they also discuss enthusiastically and deliver logic reasoning toward the topic being discussed.

The students in the sample of the research have made significant improvement in their post-test after the implementation of CBA in the classroom. However, there are several problems that currently appear during the research being conducted. Firstly, the students lack vocabularies that hinder them to comprehend the humor message in the spoof text, Secondly, Students' writing basic skills that make them difficult to convey their idea, feeling and comprehension in form of simple writing when dealing with longanswer questions.

To cope this gap, prior to teaching spoof text, English teachers are highly

168 | IJET| Volume. 9, Issue 2. December 2020 
advisable to find out the text related to students' daily activity (Perwira, 2019) and give some hints such as glossaries related to the spoof text given, so the students can easily comprehend the humor messages in the spoof text and dealing with student answering ability. They are also advised to give the answering framework that guides them to answer the questions more easily.

Based on the result of this study, CBA has been proved as an effective approach to improve student's reading comprehension. Beforehand, there are several items that should be taken into consideration to support the success of this approach Therefore, some suggestions based on several factors are proposed. It is advisable to find out the simple spoof text at the first time to gradually build students' comprehension. The teacher can ask their students about which topic they like most to be analyzed and comprehended and let the students sometimes choose what kind of topics they want. The writer recommended the teachers that they should apply more methods and techniques which are easy for the students to understand and which are enjoyable for the students. The teacher also has to make sure that they have prepared all the materials including the procedure of implementing the approach and the materials should be appropriated with the students' level.

For the next researchers who are interested in investigating similar approach, it is highly recommended to have another research in the category of another material and also another school as a research site. It aims to see the significance of CBA in improving students on spoof text. The treatment can be implemented longer and modified by combining the CBA with other approaches or strategies such as Contextual Teaching Learning (CTL). It is aimed to improve the students' awareness about the existence of culture in language and it can improve their reading comprehension because the research can compare the Indonesian spoof text from several regions with American or British spoof text. Moreover, this thing can create a new field to be studied which still relates to spoof text as the essential lesson for the students.

It is also imperative to have several research instruments. They can be modified from reading comprehension oriented to be specific writing elements. For instance; the students are asked to write their own spoof or funny story. This alternative research objective will certainly be very challenging because it is not only improving the students 'comprehension but also their writing skill in recalling their funny experiences systematically based on the generic structure of a text. In addition, it enables the students to think and write in more systematic way.

\section{CONCLUSION}

This study is intended to investigate the CBA in improving students' reading comprehension on spoof text. Based on the result of data analysis, it showed that there was a significant difference between the mean score of the pre - test (53.45) and the post-test (58.39.). Furthermore, the result of the t-test (5.707) was relatively higher than the $t$ - table (2.018) for 0.5 percent level of significance. Therefore, the null hypothesis

169 | IJET| Volume. 9, Issue 2. December 2020

Copyright 2020 Rudi Suherman, and Ana Yusyfiana are licensed under Creative Commons AtrributionShareAlike 4.0 International License 
(Ho) was rejected, and the alternative hypothesis (H1) was accepted. It means that based on statistical results, the culture-based approach is proved as an effective approach in improving students' reading comprehension on spoof text. The statistical computation shows that there is a significant difference between the mean of experimental group and control group $(\mathrm{p}<0.05$, which $\mathrm{p}=0.000)$. The students score increase on five aspects i.e. genre, discourse, register, grammar and graphic feature as the assessment criteria for a text comprehension.

The CBA can be applied more effectively if the students have prior knowledge of their own certain information regarding the humor, senses of humor and cross culture understanding. In addition to this, CBA should be applied systematically. The teacher is advisable to build the common ground related to the approach. Furthermore, they should also teach the lesson from the easiest par through the most difficult one. From the simplest text gradually through the hardest one. It relatively can help the students to improve their reading comprehension about American or British humors in which spoof text originally come from. It also aims to accommodate all students 'level of comprehension; high, medium, and low. Besides, the teacher's role in explaining the spoof text using the approach is highly essential. They become one of the key factors that determine the success of CBA implementation.

\section{E. REFERENCE}

Alwasilah, and A Haedar. 2011. Pokoknya Kualitatif : Dasar-Dasar Merancang Dan Melakukan Penelitian Kualitatif. Jakarta: Pustaka Jaya.

Booth, Sara. 2007. "Repositioning Research as Writing to Improve Student Learning." Australian Journal of Teacher Education 32, no. 4: 1.

Creswell, Jhon. 2013. "Research Design Qualitative Quantitative and Mixed Methods Approaches." Data Analysis Workshop 1, no. 9: 270. https://doi.org/https://doi.org/10.1017/CBO9781107415324.004.

Creswell, John W. 2007. Creswell, J.W. 2007. Qualitative Inquiry \& Research Design Choosing among Five Approaches , 2nd Edition.Pdf. 2nd editio. California: Sage Publication, Inc.

Elgort, Irina, Marc Brysbaert, Michaël Stevens, and Eva Van Assche. 2018. "Contextual Word Learning during Reading in a Second Language: An EyeMovement Study." Studies in Second Language Acquisition 40, no. 2: 341-66.

Emilia, Emi. 2012. "SFL Genre-Based Pedagogy and Student Empowerment." In The 61th TEFLIN International Conference, 882-86.

Emilia, Emi, and Fuad Abdul Hamied. 2015. "Systemic Functional Linguistic Genre Pedagogy (SFL GP) in a Tertiary EFL Writing Context in Indonesia." TEFLIN Journal 26, no. 2: 155-82.

Emilia, Emi, and Tazanfal Tehseem. 2013. "A Case Study in an Australian Primary School." Pakistan Journal of Social Sciences (PJSS) 33, no. 1: 121-35.

170 | IJET| Volume. 9, Issue 2. December 2020 Copyright 2020 Rudi Suherman, and Ana Yusyfiana are licensed under Creative Commons AtrributionShareAlike 4.0 International License 
Evha, Nazalatus, and Sa'adiyah. 2019. "The Effect of Using Sequenced Pictures on Students' Ability to Write Narrative." IJET (Indonesian Journal of English Teaching) 8, no. 2: 8-14.

Handayani, Nurma Dhona, and Khairul Harha. 2016. "Problems in Writing Spoof Texts." Studies in English Language and Education 3, no. 1: 12-25.

Jack, Fraenkel, E Norman, and Wallen. 2017. How to Design and Evaluate Research in Education. McGraw-Hill. Vol. 91.

Lim, Fei Victor. 2018. "Developing a Systemic Functional Approach to Teach Multimodal Literacy.” Functional Linguistics 5, no. 1: 13.

Ningsih, Harni Kartika. 2016. "Multilingual Re-Instantiation : Genre Pedagogy in Indonesian Classrooms (PhD Thesis)," no. February.

Perwira, Susilo Adi. 2019. "Textbook Readibility Assessment of K13 English Textbook For Twelfth Grade." IJET (Indonesian Journal of English Teaching) 8, no. 2: $38-47$.

Phillips, June K., and H. H. Stern. 1986. "Fundamental Concepts of Language Teaching." The Modern Language Journal 70, no. 1: 56. https://doi.org/10.2307/328070.

Renandya, Willy A. 2007. “The Power of Extensive Reading." RELC Journal 38, no. 2: $133-49$.

Setiawan, Niko Albert, and Ouda Teda Ena. 2019. "Montessori Junior High School Students' Perceptions on Their Self-Efficacy in Reading." IJET (Indonesian Journal of English Teaching) 8, no. 2: 26-37.

Vivona, Brian D. 2014. “"To Laugh or Not to Laugh': Understandings of the Appropriateness of Humour and Joking in the Workplace." The European Journal of Humour Research 2, no. 1: 1-18. 